\title{
A RELAÇÃO ENTRE O DIREITO INTERNACIONAL PÚBLICO E O DIREITO DO PETRÓLEO: ESTUDO DO CASO ENTRE TIMOR-LESTE E AUSTRÁLIA
}

\section{ARTIGO ORIGINAL}

PEREIRA, Jeremias ${ }^{1}$

PITHAN, Lívia Haygert ${ }^{2}$

PEREIRA, Jeremias. PITHAN, Lívia Haygert. A relação entre o Direito Internacional Público e o Direito do Petróleo: Estudo do caso entre Timor-Leste e Austrália. Revista Científica Multidisciplinar Núcleo do Conhecimento. Ano 04, Ed. 12, Vol. 02, pp. 31-51. Dezembro de 2019. ISSN: 2448-0959, Link de acesso: https://www.nucleodoconhecimento.com.br/lei/direito-internacional-publico

\section{RESUMO}

O presente artigo tem como objetivo analisar o Direito do Mar e do Petróleo para entender os motivos que geraram, por mais de uma década, o conflito entre o TimorLeste e a Austrália referente à definição de fronteiras marítimas definitivas. O TimorLeste já foi explorado e invadido por diversas nações. Por causa da abundância de petróleo e gás natural, sofreu para conquistar sua independência em 2002, assim como lutou para usufruir do seu território marítimo até 2018, a partir desse novo contexto do tratado de fronteira marítima assinado entre Timor-Leste e a Austrália. A Linha mediana de equidistância foi o parâmetro utilizado para definir as fronteiras definitivas timorenses, concedendo o direito de usufruírem de seu território marítimo. O pacto definitivo sobre fronteiras contribuiu muito com o desenvolvimento do Timor-

\footnotetext{
${ }^{1}$ Acadêmico do Curso de Direito da Escola de Direito da Pontifícia Universidade Católica do Rio Grande do Sul - PUC-RS.

2 Orientadora. Doutorado em Direito Privado. Mestrado em Direito. Graduação em Direito.
} 
Leste, devido à exploração de riquezas do mar, além de reconhecer a necessidade do país de que as empresas petrolíferas auxiliem na evolução deste de maneira específica e pontual. Este precisa agora ser ratificado pelos parlamentos nacionais de ambos os países. O processo de ratificação deve ser concluído em 2019. Atualmente, o Timor-Leste procura negociar suas fronteiras marítimas com a Indonésia, mas estas foram suspensas durante o processo de conciliação obrigatória com a Austrália. Agora que este processo terminou, os dois países podem retomar suas discussões novamente.

Palavras-chave: Direito do petróleo, Direito internacional, Direito do mar.

\section{INTRODUÇÃO}

Há mais de uma década, a Austrália e o Timor-Leste discordam em relação às fronteiras marítimas de cada um desses Estados. A disputa ocorre em virtude do direito à exploração do petróleo e outras riquezas do mar e dos obstáculos para o desenvolvimento econômico e político do Timor-Leste, após tratado assinado com a Austrália. Assim, o presente artigo se desenvolve na área do Direito Internacional público, especificamente na do Direito do Petróleo.

Questiona-se se o tratado entre a Austrália e Timor-Leste, referente à definição de fronteiras marítimas, foi equilibrado, preservando integralmente o direito dos timorenses. Quais os obstáculos para evitar que essa nação volte a ser explorada desproporcionalmente por outras nações e possa se desenvolver, a partir de 2019 ?

A relevância desta pesquisa se justifica pelo fato da necessidade de respeito às fronteiras marítimas do Timor-Leste pela Austrália. No século XXI, apesar da existência do Direito internacional e Direito do petróleo, a Austrália não tinha interesse de realizar um Tratado em que fossem reconhecidos os direitos do Timor-Leste de receber o percentual adequado, referente à exploração de petróleo de seu território marítimo. A fragilidade econômica histórica desse país com espaço terrestre muito inferior ao marítimo tornou-o alvo de exploração de países como a Indonésia e Austrália. Apesar de ter ocorrido um Tratado permanente entre o Timor-Leste e 
Austrália em 2018, é necessário explorar diversos documentos jurídicos que tratem sobre Direito do Mar e do Petróleo para construir alicerces jurídicos internacionais, com objetivo de multiplicar os instrumentos de defesa contra outras nações que tenham a intenção de explorar indevidamente o espaço territorial do Timor-Leste, em virtude da fragilidade econômica atual. ${ }^{[3]}$

O Timor-Leste, até 1975, pertencia a Portugal, seus colonizadores. A partir de 1976, a Indonésia invadiu-o e passou a explorá-lo, e somente com auxílio da Organização das Nações Unidas (ONU) este país elegeu em 2001 o seu primeiro presidente da república, transformando-se em um Estado independente e membro da ONU em 2002. Apesar da independência, o Timor-Leste sofreu com as tiranias da Austrália ao não receber os recursos financeiros referentes à exploração do seu território marítimo. Portugal, Indonésia e Austrália jamais investiram adequadamente no Timor-Leste, apesar de terem arrecadado milhões com a extração de petróleo daquela região, assim como com outras riquezas. Em razão de décadas dos baixos investimentos financeiros, a nação timorense necessita se desenvolver muito política e juridicamente para que ocorra ao desenvolvimento econômico. ${ }^{[4]}$

O objetivo geral deste artigo científico consiste em analisar o Direito Internacional Público e do Petróleo para entender os motivos que geraram há mais de uma década o conflito entre o Timor-Leste e a Austrália referente às fronteiras marítimas. Para compreender a problemática que envolve o território marítimo do Timor-Leste, vários objetivos específicos foram traçados, tais como

a) apresentar uma visão geral, política, histórica, jurídica e econômica do Timor-Leste e a sua relação com a Austrália;

b) analisar o Direito Internacional, relativo ao Mar;

c) explorar o Direito ao Petróleo;

d) analisar os tratados sobre as fronteiras entre Timor-Leste e a Austrália.

O presente artigo tem seu desenvolvimento dividido em quatro partes: serão analisadas, ao longo da pesquisa, as possibilidades de evolução político-social, 
histórica, jurídica e econômica do Timor-Leste, para alcançar, analisar e verificar se o Tratado entre Austrália e Timor-Leste de fato vai contribuir para o avanço da sociedade timorense. A partir dessas informações, será necessário entender os motivos que conduziram o povo do Timor-Leste a possuir um nível de desenvolvimento baixo em diversas áreas.

O primeiro capítulo trata dos aspectos históricos e geográficos, além da exploração do Timor-Leste por outras nações, em um contexto histórico, para que se compreendam os motivos do atual contexto jurídico, econômico, político e social desse país.

No segundo capítulo, exploram-se aspectos sobre as fronteiras do mar do Timor-Leste e a importância das relações internacionais para esse país. Essa análise tem a função de observar os fatores que favorecem que o povo timorense volte a ser vitimado por exploradores, devido a sua fragilidade econômica nos dias de hoje. Para compreender os mecanismos de defesa de um Estado em relação aos ataques marítimos, é necessário abordar o Direito Internacional do mar. Essa parte do Direito Internacional trata de normas e princípios acordados internacionalmente, relacionados com a propriedade, o uso, a exploração e a proteção do mar e dos seus recursos mundialmente. ${ }^{[5]}$

No Terceiro capítulo se explorará o conceito e a importância do petróleo e a sua relevância para o desenvolvimento das nações que possuem um enorme espaço territorial marítimo e um pequeno espaço terrestre, como o Timor-Leste.

O petróleo foi descoberto no século XIX e, desde o seu surgimento, houve transformações importantes na humanidade, É uma mistura homogênea de compostos orgânicos, principalmente hidrocarbonetos, insolúvel em água. Essa fonte de energia também é conhecida como bruto. Desde 1859, é considerado como uma preciosidade e, no século XXI, é ferozmente cobiçado pelo relevante papel que desempenha no mundo moderno. A busca desenfreada da Austrália e da Indonésia por poder e desenvolvimento econômico gerou diversos conflitos com o Timor-Leste em razão da ambição de determinados países de explorar o território marítimo que 
não lhes pertencia. É de extrema necessidade entender como ocorre a extração de petróleo, assim como recursos como o gás natural, para compreender os motivos que levaram à exploração indevida por décadas do petróleo timorense. [6]

Posteriormente, no quarto capítulo se apresentam os obstáculos para o desenvolvimento do Timor-Leste. A relação com a comunidade internacional é de extrema relevância para que ocorra o desenvolvimento desse país. Avanços na esfera jurídica e política são essenciais para a evolução econômica. As empresas responsáveis pela exploração dos recursos naturais do território marítimo devem negociar com profissionais timorenses preparados e capacitados para que os acordos proporcionem muitas vantagens ao Timor-Leste. ${ }^{[7]}$

O presente estudo não tem o propósito de esgotar toda a matéria, mas, sim, estimular as discussões acerca do Conflito entre o Timor-Leste e a Austrália. A técnica de pesquisa utilizada neste trabalho consistirá em pesquisa bibliográfica, por meio de análise de doutrinas, artigos científicos, bibliotecas virtuais, assim como pesquisas em textos legais oriundos de sites reconhecidos como veículos de informações fidedignas credenciados pelo governo do Timor-Leste. $O$ método adotado será o indutivo, processo pelo qual o aluno, por meio de estudo de diversos posicionamentos de doutrinadores, partirá de diversos entendimentos particulares de determinados autores, para chegar a diversas conclusões gerais. Será realizada uma exploração bibliográfica em relação ao assunto, de maneira específica, a cada subcapítulo do sumário para alcançar uma conclusão geral da problemática. ${ }^{[8]}$

\section{TIMOR-LESTE, GEOGRAFIA, HISTÓRIA, ECONOMIA E POLÍTICA}

A República Democrática de Timor-Leste é um país costeiro. Seus principais produtos econômicos são o inhame, o milho, o café, o fumo, a borracha, o sândalo branco, o gado bovino, os suínos, os búfalos, entre outros. Esse país está localizado na ilha de Timor e tem fronteiras com a Indonésia e Austrália. Seu território corresponde a trechos dessa ilha, porque, em 1975, época da independência de Portugal, a outra metade do arquipélago não pertencia mais ao domínio português. Em razão dessa situação, atualmente existe uma parte da ilha que é território da Indonésia. Situa-se 
no Sudeste da Ásia, na borda meridional do arquipélago indonésio, a noroeste da Austrália, próximo da Oceania. A Sul, encontra-se a 250 a 400 milhas náuticas, do outro lado do mar do Timor, com o continente australiano.

O território marítimo desse país, que possui abundância de petróleo e gás natural, sempre atraiu a cobiça dos diversos países. Tratados e invasões que prejudicaram os timorenses em diversos períodos históricos são oriundos da vontade de invadir e tomar posse para se tornar autoridade legítima para realizar exploração do mar do Timor-Leste. Com a finalidade de obter vantagem, a Austrália foi o único país no mundo que reconheceu, oficialmente, a anexação ilegal do Timor-Leste pela Indonésia na década de 70, apesar de existir uma resolução do Conselho de Segurança da Assembleia da Organização das Nações Unidas que condenava essa invasão. ${ }^{[9]}$

Figura 1 - Imagem fronteiras marítimas do Timor-Leste

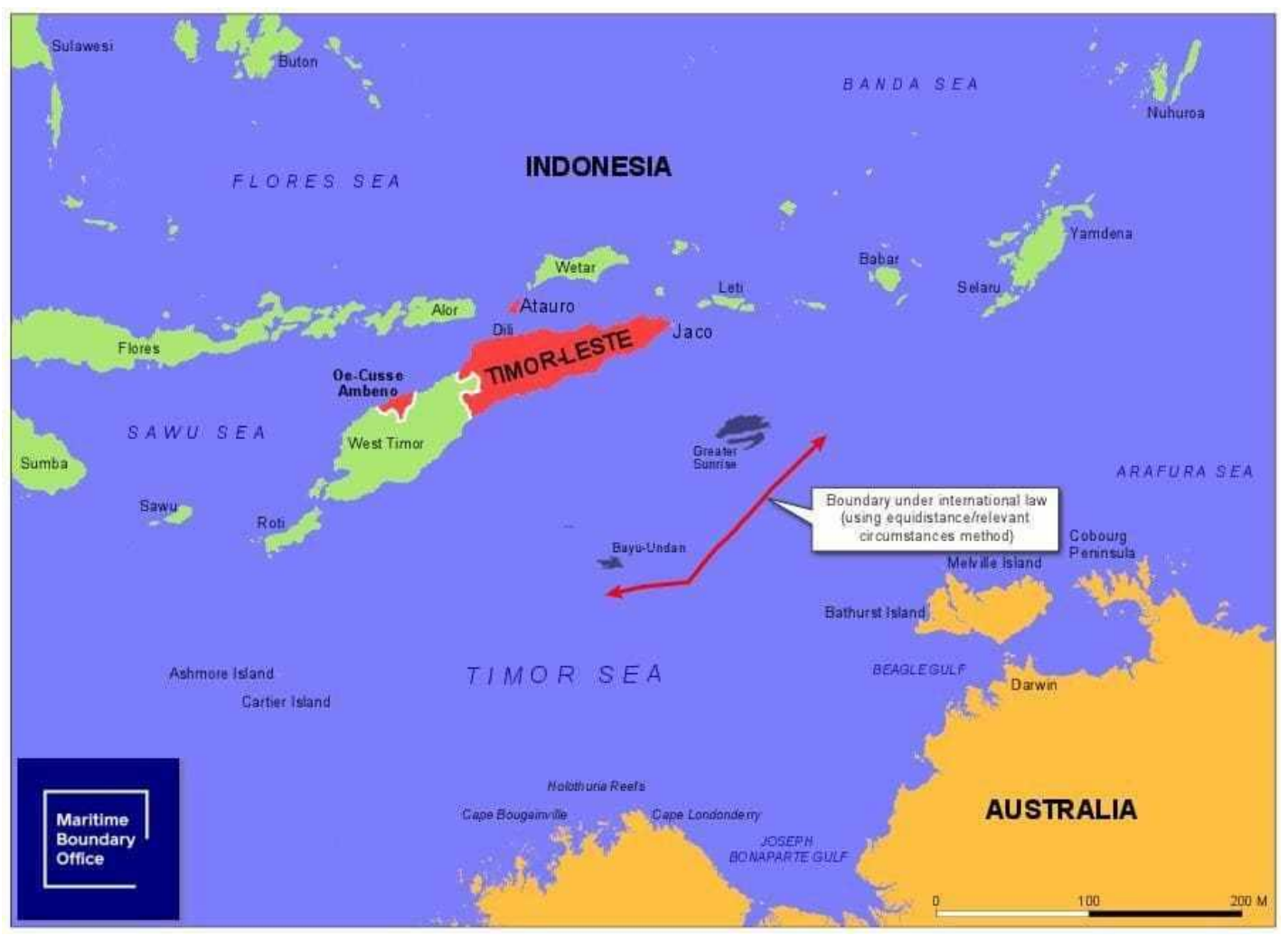

Fonte: Maritime Boundary Office (2018)[10] 
O Timor-Leste já foi explorado por Portugal, Japão, Indonésia e Austrália em diferentes períodos. O contexto histórico dessa república é um fator que revela as causas da atual situação social, política e econômica dessa nação. Esse país, que possui um pequeno território terrestre e aproximadamente um milhão de habitantes, necessita se desenvolver muito em diversas áreas por ser um país jovem. Portugal foi o dominador do Timor-Leste de 1515 até 1975 e pouco investiu em seu crescimento. De 1942 a 1945, na Segunda Guerra Mundial, foi ocupado pelo Japão, mas logo os portugueses retomaram a autoridade dessa colônia. Em abril de 1975, surgiu em Portugal um movimento de política das forças armadas, popularmente conhecido como 3D, com a finalidade de descolonizar, democratizar e desenvolver. Nesse período, no Timor-Leste nascia um movimento revolucionário conhecido como FRETILIN, Frente Revolucionária de Timor-Leste Independente. No dia 28 de novembro de 1975, ocorreu a sua independência, impulsionada pelo movimento dos timorenses. A independência foi observada apenas por dez dias. ${ }^{[11]}$

A Indonésia, em julho de 1975, invadiu o Timor-Leste, permanecendo aproximadamente por vinte e seis anos naquele território, momento em ocorreram muitas mortes por doenças e escassez de alimentação. A comunidade internacional se comoveu com o genocídio que ocorria lá. Em 1999, a ONU, juntamente com Portugal, intermediou um acordo com a Indonésia, o qual tratava sobre a possibilidade de realização de um referendo. Em agosto de 1999, os timorenses optaram pela independência com maioria dos votos, pois $78 \%$ da população não aceitava mais o massacre que sofria. Mas os dominadores não aceitaram a libertação. Militares Indonésios torturaram e massacraram o povo. Muitos timorenses fugiram para parte ocidental da ilha, enquanto tudo que foi construído ao longo da invasão era destruído naquele país. Com objetivo de controlar o massacre, a ONU adotou a Resolução 1246, de agosto de 1999, para constituir uma força multinacional para estabilizar a situação. Após a retirada da Indonésia, o Timor-Leste passou a ser destinatário de auxílio da comunidade internacional, pois houve perdas humanas e materiais incalculáveis. Em 20 de maio de 2002, com auxílio da ONU, ocorreu a restauração da independência da República Democrática do Timor-Leste, observando-se o primeiro governo eleito democraticamente. ${ }^{[12]}$ 
O interesse da Austrália pelo Timor-Leste não é novidade. Os australianos tiveram informações de que no Mar do Timor-Leste existia muito gás e petróleo. Desde a descoberta, em 1960, de que havia riqueza no mar timorense os governos estrangeiros tentaram dominar a ilha. Na década de 1970, a Austrália foi o único país que reconheceu que a metade ocidental da ilha do Timor pertencia à Indonésia. Acontece que, em 1970, uma empresa australiana chamada de Woodside Petroleum encontrou uma enorme reserva de gás na região conhecida como Os Campos Sunrise e Troubadour ou Greater Sunrise. ${ }^{[13]}$ A intenção de negociar para obter vantagens territoriais foi uma das razões por que os australianos ignoraram o parecer negativo da comunidade internacional, que não concordava com conduta da Indonésia de invadir a parte ocidental da ilha do Timor. Interessadas em ter lucros com a descoberta de riquezas no mar do Timor-Leste, a Indonésia e Austrália assinaram o tratado. Esse documento versava sobre as fronteiras marítimas entre os dois países, mas a Austrália ficou com o território em que se localizavam as reservas de gás. Descontente com o Tratado que assinou, em 1975, a Indonésia invadiu a Austrália para obter porcentagem sobre a exploração dos recursos do gás daquela região. Os timorenses não estavam de acordo com o tratado que repartia as riquezas de seu território entre a Indonésia e Austrália, porém as duas nações estrangeiras envolvidas no acordo internacional ignoraram o posicionamento mundial, contrário ao seu pacto. Em 20 de maio de 2002, data do restabelecimento da independência do Timor-Leste, o país procurou tomar posse do território que lhe era de direito. O Timor já não pertencia à Indonésia. Os tratados que haviam sido pactuados antes da independência não possuíam mais valor. ${ }^{[14]}$

A Austrália, em 2002, com objetivo de permanecer dominando o território marítimo que pertenceria ao Timor-Leste, retirou-se de todos os procedimentos vinculativos sobre fronteiras de que fazia parte. Em 2006, houve um Tratado entre Austrália e Timor-Leste sobre Determinados Ajustes Marítimos no mar do Timor, acordo que descontentou os timorenses porque servia para evitar alterações das negociações jurídicas ou ações jurídicas por cinquenta anos. Foi em 2016 que o povo que se sentiu prejudicado em razão do Tratado notificou os australianos que resolveria o problema 
das fronteiras marítimas, através da conciliação obrigatória prevista na Convenção das Nações Unidas, artigo 298 e anexo V, que trata sobre Direitos do mar. ${ }^{[15]}$

A dominação do Timor-Leste por outras nações, em diferentes períodos históricos, prejudicou-o muito. Diversos reflexos da exploração da Indonésia e da Austrália são sentidos no desenvolvimento do povo timorense em várias áreas. Desde 2002, às vésperas da independência do Timor-Leste, os australianos se retiraram de diversos tratados internacionais para evitar a perda da exploração do território marítimo que não the pertence. Os australianos e os timorenses possuem territórios separados por menos de 400 milhas náuticas. Devido à proximidade entre as duas nações, seus territórios marítimos precisam ser definidos de maneira peculiar e específica, conforme o princípio de equidade. É essencial aprofundar o conhecimento sobre o Direito do mar e o Petróleo para compreender os motivos de fato e direito que legitimam a luta do povo timorense por seu território marítimo. [16]

\section{DIREITO DO MAR E O PETRÓLEO}

O Direito do Mar pertence ao Direito Internacional, que observa a soberania e jurisdição dos Estados, definindo a extensão de seu domínio marítimo. Ele também regulamenta diversos outros temas como a exploração de recursos existentes no leito e no fundo do mar, além da preservação e conservação do meio ambiente marinho. ${ }^{[17]}$ Uma das maiores riquezas encontradas no fundo do mar timorense é o Petróleo, que se destaca por ser um líquido negro viscoso, inflamável, menos denso que a água. Ele é constituído por uma mistura de hidrocarbonetos, moléculas compostas por átomos de Carbono e Hidrogênio, além de moléculas de Enxofre, Nitrogênio, Oxigênio e Íons Metálicos, e encontra-se localizado em reservatórios subterrâneos naturais. ${ }^{[18]}$

A Conferência sobre os Direitos marítimos ocorreu em Genebra, em 1958. Em 1969, foi ratificada por quase todos os países do mundo. Ela versa sobre diversos assuntos ou temas que tratam da estreita ligação no espaço oceânico entre as nações. A Convenção das Nações unidas sobre Direitos do Mar (CNUDM), de 1982, foi assinada em Montego Bay, na Jamaica, apesar de ter surgido na conferência de Genebra. Nesse documento se encontram regras e princípios do mar territorial, zonas 
contíguas, ${ }^{[19]}$ econômicas e plataforma continental. ${ }^{[20]}$ No que se refere à soberania do Estado costeiro sobre as águas adjacentes, ${ }^{[21]}$ ela regula todos os países que a adotaram, aceitaram ou ratificaram. Também há normas relacionadas sobre a gestão dos recursos marinhos e controle da poluição. ${ }^{[22]}$

A CNUDM determina que o mar do litoral possua 12 milhas marítimas, ou seja, $22 \mathrm{~km}$. No plano vertical, estende-se ao espaço aéreo, tendo-o como seu limite. A água marítima da superfície se limita através do contato com o leito oceânico, solo, assim como todo subsolo é regido pelo regime jurídico do mar territorial. ${ }^{\left[{ }^{[3]}\right.}$ Foi garantida pelo Direito do mar aos Estados costeiros a exploração econômica exclusiva numa aérea de 200 milhas marítimas, mas essa regra não se aplica a Estados que possuem menos de 400 milhas de distância, a partir de suas zonas contíguas. ${ }^{[2]}$

Figura 2 - Mar territorial

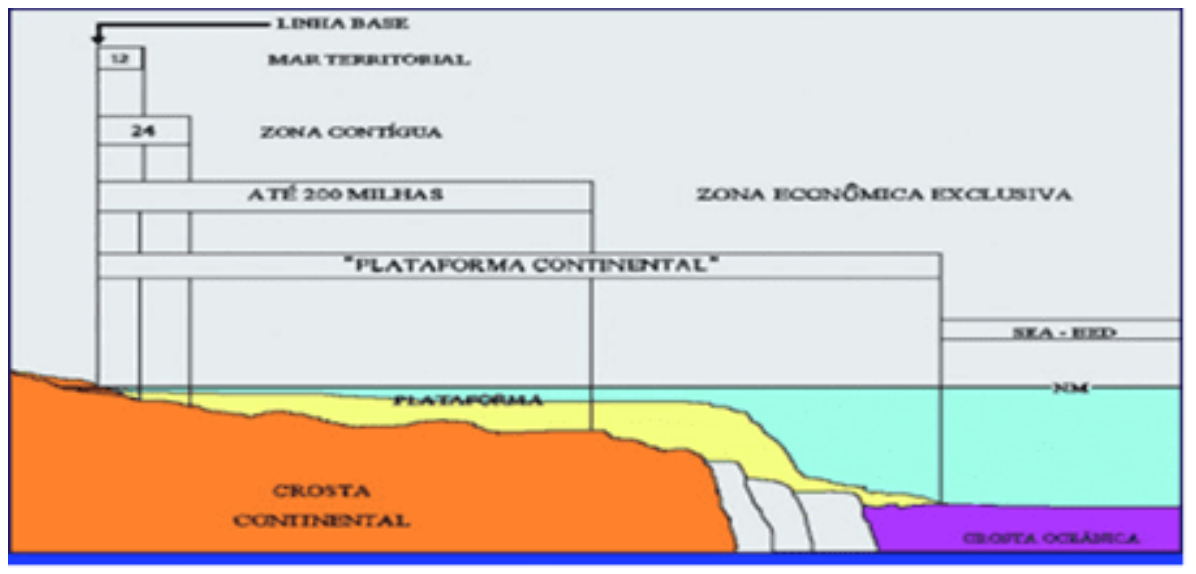

Fonte: GUSMÃO (2018).

O Mar Territorial é a zona localizada entre as águas interiores e o Alto mar. Ele é a continuação da soberania de um país costeiro que ultrapassa o seu território e suas águas, conforme artigos $2^{\circ}$ e $3^{\circ}$ da CNUDM. ${ }^{[25]} \mathrm{O}$ Estado exerce soberania em relação ao seu mar territorial, espaço aéreo, assim como ao leito e subsolo sob o mar territorial, conforme art. 02 a 32 da Convenção de Direitos do Mar. ${ }^{[26]}$ O limite exterior do mar territorial de cada nação é de vinte e dois quilômetros. O Estado exerce sua jurisdição sobre atividades de interesse nacional na zona marítima contígua, que é 
fixada em 12 milhas. A Convenção das Nações Unidas criou a Zona Econômica Exclusiva, ZEE, para equilibrar os interesses entre os países. Esta é uma zona localizada além do Mar Territorial. Ela se refere à área próxima da zona contígua e se estende até 200 milhas da costa. O Estado tem o direito de navegar, sobrevoar, instalar cabos e dutos marinhos, além do de explorar os minerais encontrados no solo e subsolo marinhos. O Timor-Leste e a Austrália são separados por menos de 400 milhas de distância, e por esse motivo essa regra não soluciona os conflitos sobre fronteiras entre as duas nações. ${ }^{[27]}$

Os timorenses e os australianos são povos que pertencem a Estados com costas adjacentes ou situadas frente a frente. Eles não preenchem os limites estabelecidos pela Convenção das Nações Unidas para aplicação dos Direitos do Mar, relacionados à soberania do Estado no mar territorial. A distância da costa litorânea entre os países é de 300 milhas. Estes países devem proceder à delimitação de fronteiras marítimas através de acordo, conforme o determinado pelas regras do Direito Internacional. As nações devem alcançar uma solução equitativa, ou seja, justa e equivalente.[28]

A Convenção de Genebra possui critérios para delimitação de paralelos. O método da linha mediana é utilizado em circunstâncias especiais para Estados com costas opostas. Ele regula um reajustamento da linha mediana entre os países. A Convenção sobre o Direito do Mar determina que, diante da inexistência de distância de 400 milhas para separação entre dois países, deva ser utilizado o princípio da equidistância. [29]

A Indústria de Petróleo é extremamente importante. A sociedade atual depende dele e de seus derivados. Trata-se de um combustível fóssil, fonte energética elétrica para grande parte dos países desenvolvidos e em fase de desenvolvimento. É essencial para fabricação de uma gama de produtos, como diesel, querosene e gasolina. Também está presente nos insumos e na indústria petroquímica, através da parafina e nafta. Muitos medicamentos têm na sua composição derivados do petróleo. É impossível refletir sobre os atuais moldes da vida humana sem asfalto, plásticos e aspirinas. O petróleo pode ser observado em combustíveis utilizados para locomoção das pessoas. Está contido em uma infinidade de produtos químicos e petroquímicos 
fundamentais para o desenvolvimento de uma nação. Por sua vasta aplicabilidade e por ser uma fonte esgotável de energia, os australianos ignoraram o Direito Internacional do Mar por muitos anos. Eles se retiraram da CNUDM para evitar que o povo timorense tivesse direito aos lucros sobre a exploração das empresas petrolíferas Bayu Undan e Greater Sunrise. ${ }^{[30]}$

Em razão da importância do petróleo, surgiu em Viena, na Áustria, em 1960, a Organização dos Países Exportadores de Petróleo (OPEP, ou, em inglês, OPEC). As nações fundadoras foram República Islâmica do Irã, Iraque, Kuwait, Arábia Saudita e Venezuela. A finalidade da OPEP é estabelecer uma política comum ao petróleo, protegendo os rendimentos dos países produtores. Antes da criação dessa organização, os países exportadores de petróleo que detinham a maior parte das reservas petrolíferas da época pouco se beneficiavam. As enormes corporações regulavam o mercado internacional de petróleo. O valor do combustível fóssil pago aos países produtores e para revenda ao consumidor final era controlado pelas petrolíferas. As empresas estadunidenses Exxon, Texaco, Amoco e Chevro, assim como as holandesas Royal Dutch Shell e a britânica British Petroleum eram chamadas Sete Irmãs. Elas realizavam a exploração, refino, transporte e revenda do petróleo, mas somente uma pequena parte dos frutos da extração era destinada aos Estados produtores. Atualmente, a Organização das Nações Unidas também observa a atuação das petrolíferas para que possa ocorrer um acordo adequado entre os Estados produtores e as empresas extratoras de petróleo.[31]

O Timor-Leste foi explorado por décadas pela Austrália. Essa conduta foi substancialmente impulsionada por motivos econômicos, devido ao interesse nas riquezas do território marítimo timorense. Não é novidade que a Indústria do Petróleo é que motivou o afastamento da Austrália da comunidade internacional. Os australianos não se demonstraram dispostos a tratar assuntos relacionados aos Direitos do mar. $O$ interesse nos lucros sobre a extração de petróleo e gás natural da região que pertence ao Timor-Leste impediu que, por muitos anos, houvesse um acordo entre as duas nações. ${ }^{[32]}$ 
Os timorenses foram prejudicados pela Austrália desde a sua independência em 2002. Todas as reservas de petróleo e gás estão do lado timorense da linha mediana, ou seja, mais próximo do Timor-Leste do que do território australiano. A Austrália deixou de reconhecer a jurisdição do Tribunal Internacional de Justiça e da Convenção das Nações Unidas sobre o Direito do Mar para delimitar as suas fronteiras na linha mediana com o Timor-Leste, meses antes de sua independência. $\mathrm{O}$ afastamento da Austrália da CNUDM tinha a intenção de evitar a perda ou redução do espaço territorial marítimo, já que ele pertencia por direito aos timorenses. A Convenção das nações Unidas sobre Direitos do Mar determina que cada país deve delimitar como zona econômica exclusiva 200 milhas náuticas, a partir do limite exterior do seu mar territorial, 12 milhas da costa. A CNUDM também trata das grandes profundidades do mar que são conhecidas como Área ou Zona A, conforme art. 1‥ Essa área é composta pelos fundos marinhos e oceânicos e seu subsolo. ${ }^{[33]}$

Figura 3 - Linha de demarcação de fronteiras entre a Austrália

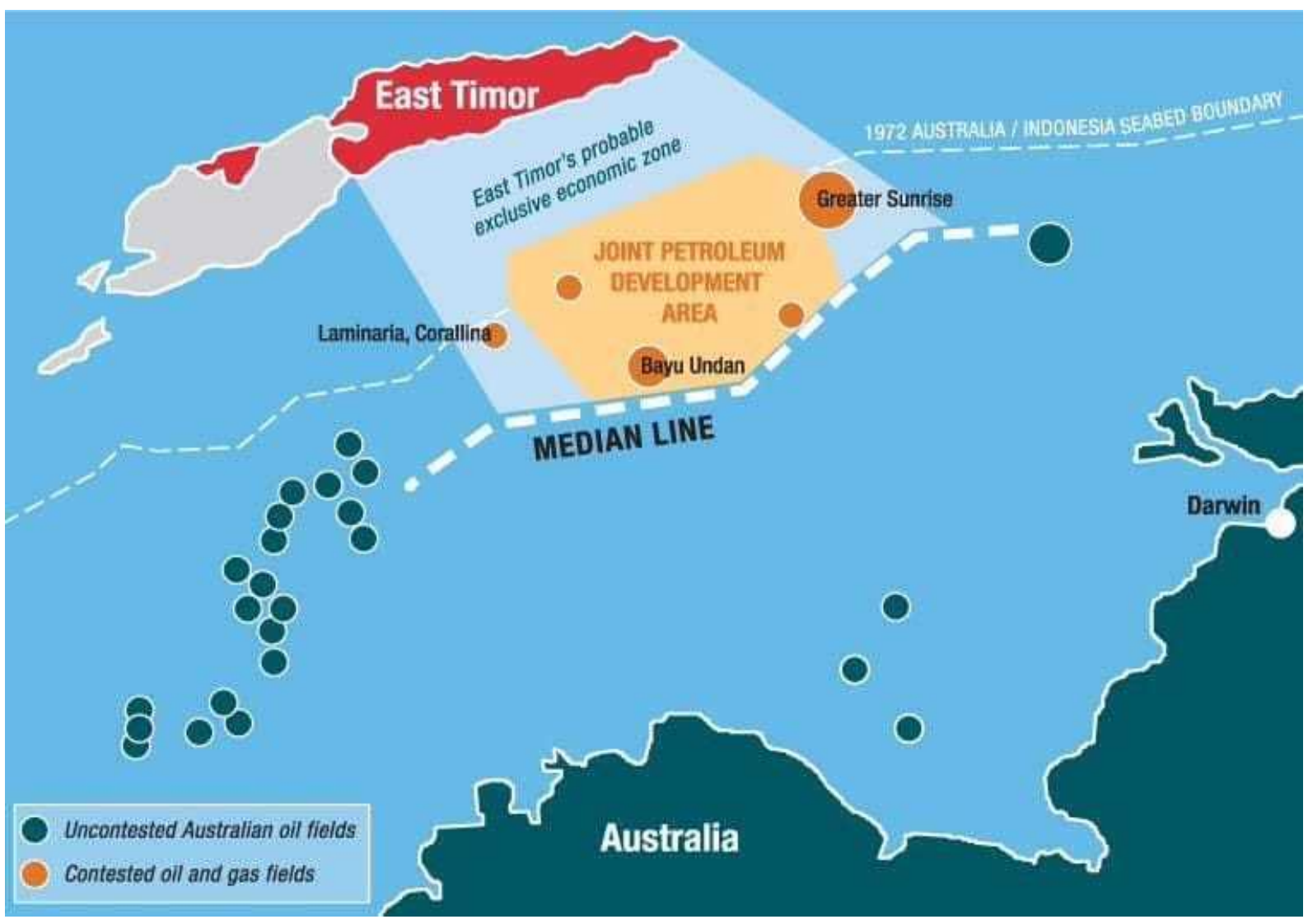

Fonte: TIMOR SEA JUSTICE (2016). [34] 
Os princípios contidos na Convenção das Nações Unidas sobre Direitos do Mar determinam que a fronteira marítima entre os dois países envolvidos deverá ser definida pela linha equidistante, ou seja, a linha mediana. A demarcação de fronteiras entre a Austrália e o Timor-Leste através do princípio da equidistância contempla o território timorense com toda zona de exploração do poço da petrolífera Bayu Undan. O campo petrolífero do Greater Sunrise se localiza na denominada Área A Zona de Cooperação e, conforme a CNUDM, esse território também pertence ao povo timorense. ${ }^{[35]}$

O petróleo é uma riqueza que se encontra em abundância no Timor-Leste. A linha mediada deve ser traçada para definir o espaço marítimo entre dois países que se separam por menos de 400 milhas náuticas. Reservatórios de gás natural e petróleo foram encontrados por empresas australianas no Timor-Leste, antes de sua independência. Por essa razão, os australianos tiveram muita resistência em realizar um tratado definitivo sobre o direito à exploração do mar timorense. As dificuldades enfrentadas por esse povo para obter seus direitos marítimos são questões importantes. Analisar os detalhes que antecederam o tratado definitivo realizado em 2018, que trata sobre as fronteiras timorenses, é essencial para compreender a proporção da evolução que esse pacto significa. [36]

\section{TRATADO ENTRE AUSTRÁLIA E TIMOR-LESTE}

Em 2002, o Timor-Leste conquistou a sua independência da Indonésia, mas, desde esse ano, as fronteiras marítimas definitivas timorenses não foram demarcadas. Os australianos, por muitos anos, não demostram interesse em tratar sobre os limites marítimos do Timor-Leste, observando as normas de direito Internacional. Eles pretendiam permanecer utilizando os recursos do mar que não thes pertencia. Apesar de terrem causado prejuízo ao desenvolvimento do Timor-Leste em diversas áreas por muito tempo, o pacto não previu o ressarcimento dos danos causados desde 2002. ${ }^{[37]}$

O povo timorense não será ressarcido pelos danos causados para sua evolução nas áreas da educação, social, econômica, política, entre outras que necessitem de 
recursos mínimos financeiros para que ocorram. Mas, ao realizar o pacto, foi observado que o Timor-Leste foi muito prejudicado ao longo dos anos pela Austrália. ${ }^{[38]}$ No sentido de incentivar o desenvolvimento, industrial, tecnológico e econômico dos timorenses, ficou acordado que a empresa que realizaria a exploração do Greater Sunrise teria que contratar os cidadãos do Timor-Leste, facilitando-Ihes a formação profissional e estimulando o desenvolvimento de seus estudos, assim como teria o dever de adotar o país como primeira opção para aquisição de bens e serviços. ${ }^{[39]}$

Objetivando evitar a perda econômica, a Austrália se retirou de diversos Tratados Internacionais de que era integrante meses antes da independência do TimorLeste. ${ }^{[40]}$ No sentido de impedir que qualquer um dos dois países deixasse de observar o pacto futuramente, as nações estipularam que o tratado não estaria sujeito a um direito unilateral de denúncia, retirada ou suspensão. No texto do documento, foi esclarecido que todas as cláusulas expressas no tratado e anexos fazem parte do pacto, não podendo ser ignoradas ou destacadas. Diante de possível litígio futuro, foi acordado que poderia ser resolvido com auxílio dos membros da Comissão de Conciliação que mediaram o pacto entre as duas nações em 2018. Porém, na permanência do desacordo sobre os temas, questões abordadas com a intervenção dos membros da Comissão de Conciliação, poderia ser interposto recurso ao tribunal arbitral, e essa segunda decisão possuiria efeito vinculativo. ${ }^{[41]}$

Em 06 de Março de 2018, ocorreu o acordo entre Timor-Leste e Austrália. Esse pacto delimita a bacia continental. Nesse documento foi demarcada a linha mediana e as fronteiras laterais, a leste e oeste da antiga zona conhecida como Timor Gap, conforme $\mathrm{o}$ art. $1^{\circ}$ do tratado de fronteiras marítimas do Timor-Leste. ${ }^{[42]} \mathrm{A}$ partir desse novo contexto se torna permitida ao Timor-Leste a realização da exploração de recursos do solo marinho como o petróleo e gás natural, além de proporcionar os benefícios aos direitos oriundos da zona econômica exclusiva. Essa nação também conquistou o direito de explorar outros recursos marítimos como a pesca, possibilitando o aumento de recursos financeiros para o país. ${ }^{[3]}$ 
Figura 4 - Tratado da Austrália e do Timor-Leste sobre fronteiras do Timor

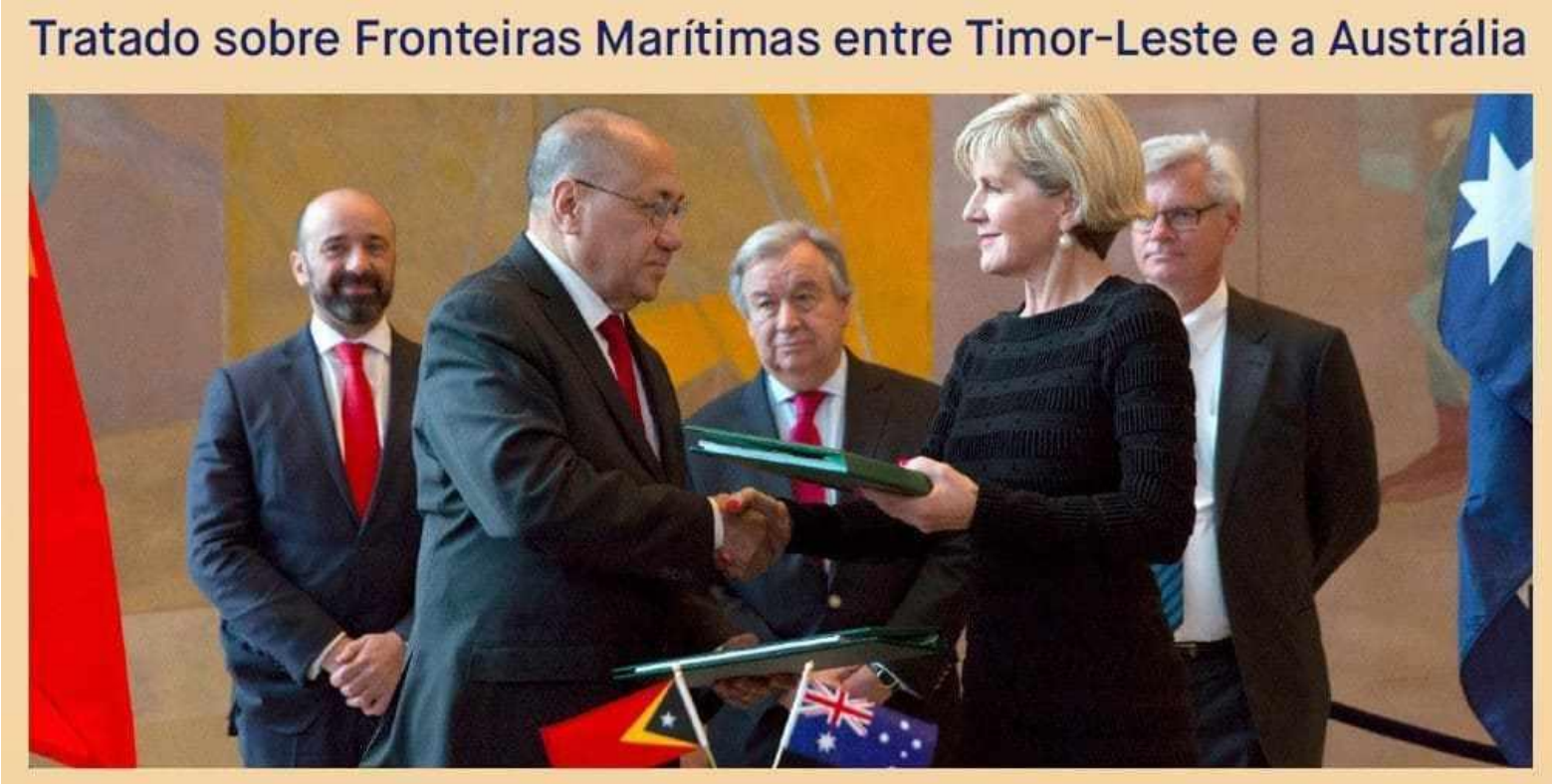

Fonte: Timor-Leste (AUSTRÁLIA, 2018).[44]

O Timor-Leste e Austrália flexibilizaram seus interesses para resolver as discordâncias que os impediam de pactuar. $\mathrm{Na}$ área territorial marítima em que se localiza o Greater Sunrise, foi acordado que pertenceria a cada um dos países envolvidos no acordo a metade dos resultados da exploração daquela região territorial marítima. Os campos de Bayu-Undan, Buffalo e Kitan integraram, totalmente, o território timorense. ${ }^{[45]}$

Os modos que as receitas seriam partilhadas entre Timor-Leste e Austrália não foram definidos, pois dependeriam de diversos fatores. Quanto maior a capacidade de desenvolver técnicas e aplicá-las, maiores seriam seus lucros. De acordo com formas de exploração dos campos do Greater Sunrise, seriam partilhados os resultados. No ano em que ocorreu o pacto, foi acordado que as receitas do campo petrolífero pertenceriam 30\% para Austrália e 70\% para Timor-Leste, se houvesse aumento da exploração por meio do desenvolvimento de Gasoduto para o povo timorense. Também foi previsto que, na hipótese de os campos do Greater Sunrise serem desenvolvidos por meio de um Gasoduto para a Austrália, as percentagens seriam modificadas, pertencendo $20 \%$ para os australianos e $80 \%$ para os timorenses. ${ }^{[46]}$ 
No tratado definitivo sobre fronteiras, conforme o art. 12 do documento legal, foi definido que a exploração do gás e petróleo da região dos campos do Greater Sunrise dependeria da definição entre as partes sobre o plano de desenvolvimento. Acontece que, após o início das atividades de exploração da região do mar que teriam as receitas partilhadas, a empresa contratada se submeteria à jurisdição exclusiva do país onde ela se localiza. Seria criado Conselho de Supervisão composto por dois representantes do Timor-Leste e um representante da Austrália. Visando encontrar soluções para os litígios, haveria um Comitê Independente de Resolução de conflitos para decisões sobre as estratégias adotadas para exploração do campo petrolífero acima referido. ${ }^{[47]}$

Por décadas, a Austrália demonstrou a intenção de obter os lucros oriundos da exploração dos campos petrolíferos integralmente. Foi necessária intervenção internacional para que o conflito sobre fronteiras entre os timorenses e australianos se reduzisse. O Tratado definitivo sobre fronteiras versa sobre a linha mediana e os limites laterais sobre o território do Timor-Leste e partilha as receitas oriundas de uma região petrolífera entre os países envolvidos. Mas esse pacto não extingue a possibilidade de existirem futuros conflitos sobre os lucros oriundos dos campos do Greater Sunrise. Muitas questões ficaram pendentes de esclarecimento, necessitando que os conflitos concretos surjam para que posicionamentos sejam adotados. Diante dessa nova situação, o povo timorense enfrentará diversos obstáculos para que possa usufruir de todas as possibilidades para o seu desenvolvimento em diversas áreas. ${ }^{[48]}$

\section{OS OBSTÁCULOS PARA DESENVOLVIMENTO DO TIMOR-LESTE}

O Timor-Leste é um Estado marítimo e não somente petrolífero. Há diversos setores que podem contribuir para evolução da nação. Por muitos anos ele foi explorado por Portugal, Indonésia e Austrália. Poucos recursos foram investidos na educação e infraestrutura. A nação foi prejudicada no desenvolvimento de diversas áreas em razão do descaso da Indonésia. Há poucos profissionais com habilidades técnicas, políticas, jurídicas e administrativas, porque, durante o período de dominação do povo, somente profissionais estrangeiros eram contratados para executar atividades nessas áreas. ${ }^{[49]}$ 
Figura 5 - Alunos de uma escola da periferia timorense

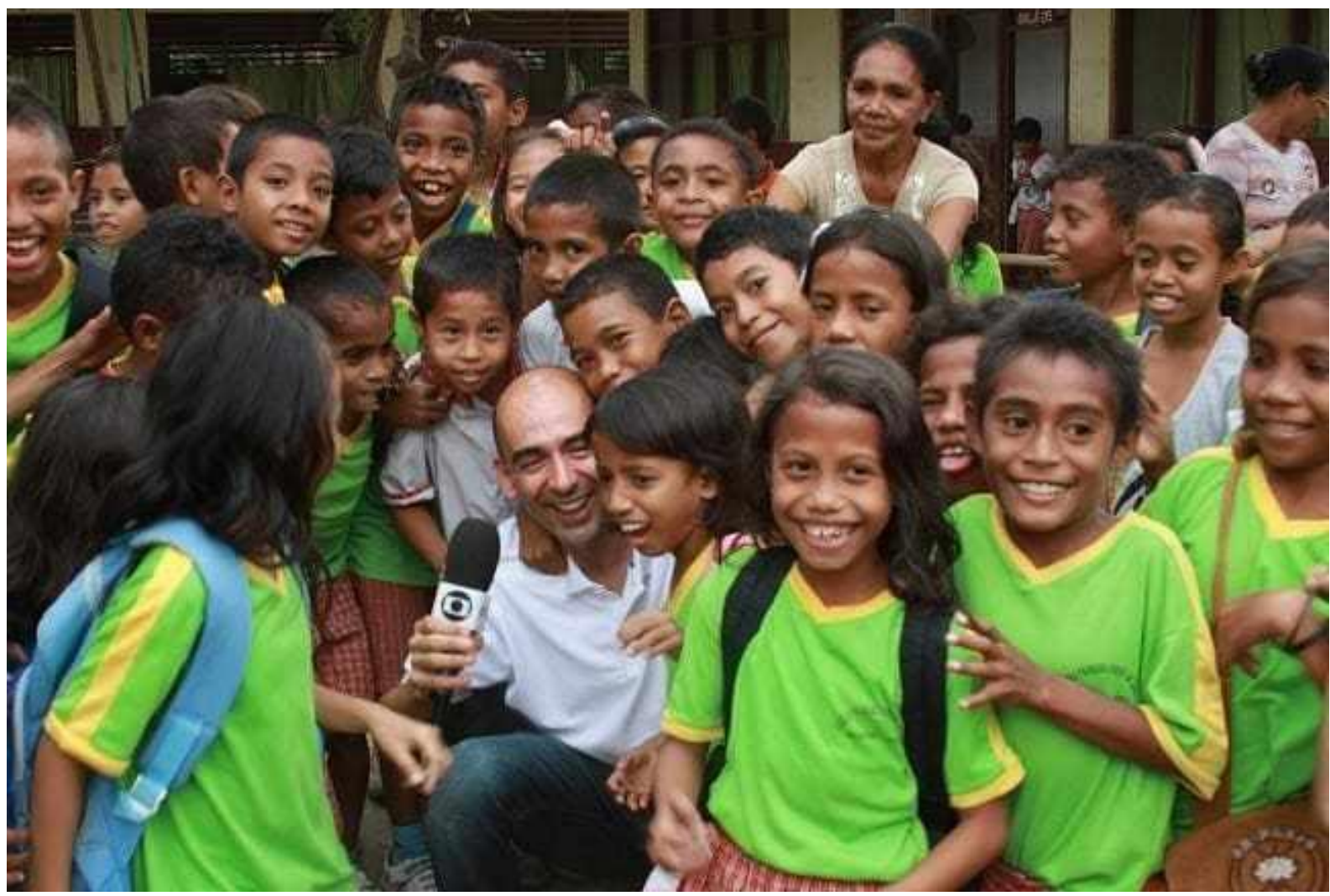

Fonte: Parceiros pela paz (2011).[50]

Desde 2011, o Timor-Leste possui um plano de desenvolvimento estratégico que contempla a evolução do capital humano, infraestrutura, economia, política e da área administrativa. A meta do governo timorense é atingir os objetivos traçados no plano de desenvolvimento até 2030. Os recursos oriundos dos direitos de exploração de seu território marítimo trarão maior velocidade na execução das metas propostas no plano de desenvolvimento timorense. O pacto da Austrália sobre fronteiras definitivas certamente gerará diversas situações peculiares e inéditas. Conhecimentos específicos sobre métodos de exploração de petróleo e gás natural serão essenciais para compreender quais alternativas trarão maiores lucros para o país. Após a ratificação do tratado, muitas normas foram estabelecidas para que os timorenses pudessem usufruir de seus direitos, mas precisarão de profissionais habilitados em diversos âmbitos. E um dos grandes desafios que Timor-Leste enfrenta é a curta experiência na administração pública, gestando grandes volumes de receitas 
financeiras, que se multiplicarão em razão do tratado definitivo sobre suas fronteiras. ${ }^{[51]}$

No documento do tratado, ficaram estabelecidas normas que envolvem empresas exploradoras internacionais de grande porte. As petrolíferas devem contribuir com desenvolvimento do Timor-Leste contratando, preferencialmente, profissionais, serviços e produtos do país. Os timorenses não se relacionarão somente com representantes do governo da Austrália, mas com experientes representes de iniciativa privada. Estrangeiros representantes do governo da Austrália ou empresas privadas de diversas nações poderão possuir vasta habilidade de negociar e tratarão com timorenses pouco experientes. O Timor-Leste possui profissionais com pouca habilidade técnica, mas essa situação não deverá comprometer o desenvolvimento. Será missão desses empresários auxiliar na educação e ensino das competências e conhecimentos exigidos dos trabalhadores para realizarem tarefas ligadas a atividades de exploração. O aumento dos recursos financeiros contribuirá com as transformações dos setores, técnicos, administrativos, políticos, jurídico, entre outros, facilitando a transposição de obstáculos para o desenvolvimento da nação. ${ }^{[52]}$

A exploração de gás e petróleo demandará que o poder legislativo do Timor-Leste esteja atento ao surgimento de fatos novos decorrentes dessa atividade. Os órgãos estatais necessitarão encontrar rápidas respostas para divergências entre o Estado, representantes de empresas exploradoras e Austrália. Apesar de a empresa contratada ter a obrigação de se submeter à jurisdição exclusiva do país onde ela se localiza, deve-se considerar a experiência e a habilidade dos representantes da iniciativa privada em manipular as negociações. É inegável que o governo do TimorLeste adota posicionamentos que contribuem para o avanço em diversas áreas do país, mas é fato que os poderes executivo, legislativo e judiciário timorense estão se desenvolvendo ainda, pelo fato de ser um país muito jovem. ${ }^{[53]}$

O Timor-Leste possui ampla experiência em combates, pois o povo se organizou contra a invasão da indonésia e obteve sua independência. ${ }^{[54]}$ Atualmente, avança em busca de proporcionar educação, infraestrutura, economia, política e adequada gestão administrativa para os cidadãos. No pacto sobre fronteiras definitivas, foi 
reconhecida a situação de fragilidade do Timor-Leste. E mecanismos para auxiliar na evolução do país foram positivados no acordo. ${ }^{[55]}$

O governo do Timor-Leste terá tarefas complexas, e será necessário um setor jurídico e administrativo preparado para atuar em novas atividades. Relatórios e planos de desenvolvimentos sobre exploração dos campos de Bayu-Undan, Buffalo e Kitan precisarão ser emitidos durante o período de transição da exploração dessa região. Esse dever demandará o conhecimento técnico específico sobre exploração de petróleo e gás. ${ }^{[56]}$ Muitos setores estão relacionados ao desenvolvimento de uma nação. As políticas de investimento em setores que possuem fontes de exploração renováveis precisam ser observadas pelo governo do Timor-Leste. Devem ser considerados os dispositivos do pacto sobre fronteiras timorenses, relacionados ao dever das empresas de auxiliar na evolução de diversos setores. O Estado terá que se esforçar para o desenvolvimento na mesma medida em que deverá exigir que a iniciativa privada contribua com a evolução do país. ${ }^{[57]}$

O crescimento econômico é fundamental para que ocorram progressos na infraestrutura, política e administração. A ascensão econômica do Timor-Leste está vinculada aos setores da agricultura, do turismo e do mar e não somente à exploração do petróleo e gás. A agricultura é essencial para o Timor-Leste, assim como tem muita relevância para diversas outras nações. A partir dela é que os alimentos são produzidos. Os produtos primários oriundos da agricultura podem ser utilizados pelas indústrias, comércio e pelo setor de serviços. Eles podem se transformar na base para a manutenção da economia nacional e internacional. ${ }^{[58]}$

A exploração da economia marítima também é crucial para evolução da nação timorense. Muitas pessoas dependem do mar e se sustentam com os recursos gerados pela pesca e colheita de espécies marinhas. Acontece que, no território marítimo desse país, existe uma passagem natural de peixe. E, através das evoluções trazidas pelo pacto definitivo sobre fronteiras, diversas espécies de peixe poderão ser exploradas por indústrias nacionais. Além do aumento de receita pelo surgimento de indústrias interessadas nas muitas espécies de cardumes que aquela região possui, essa nação se situa no Triângulo do Coral. Esse é um patrimônio cultural que poderá 
ser apreciado pelo turismo, assim como poderá servir de interesse a pesquisas científicas. As características acima relacionadas poderão gerar o aumento direto e indireto de recursos para o Estado, desde que ocorram as medidas administrativas adequadas. ${ }^{[59]}$

A infraestrutura dos portos e aeroportos timorenses também é fundamental para o crescimento país. Os parâmetros das construções estratégicas devem acompanhar as necessidades das navegações do cenário global que pelo território timorense poderão transitar. Os portos de Díli, Oe-cusse, Hera, Caravela e Com, atualmente, apresentam características inadequadas, necessitando de investimentos para serem considerados como polos industriais. Essa evolução criará oportunidades de o TimorLeste se tornar um trânsito de cargas dos petroleiros, além de torná-lo uma nação possuidora de um grande polo industrial que liga os Oceanos Pacífico e Índico. [60]

O Timor-Leste necessita continuar avançando em muitas áreas. Os setores agrícola, petrolífero, marítimo, turístico, educacional, jurídico, político e econômico necessitam de transformações. Já há um plano de política de desenvolvimento que foi criado em 2011. No entanto, é necessário adequá-lo à nova realidade em que o país se encontra, após as modificações que ocorreram pela definição de suas fronteiras marítimas definitivas. ${ }^{[61]}$ Estratégias específicas para cada setor precisarão ser retraçadas em um plano nacional interno. E, a partir desses novos objetivos, os posicionamentos com as empresas exploradoras de gás e petróleo deverão ser adotados, assim como todas as decisões do Estado serão com a finalidade de alcançar esses objetivos de crescimento. ${ }^{[62]}$

\section{CONCLUSÃO}

Timor-Leste se localiza no Sudeste da Ásia e é um país muito jovem, que obteve sua independência em 2002. Ele é vizinho da Indonésia, que se situa ao norte, e ao sul está a Austrália. Possui uma nação que se caracteriza pela sua força e luta. Esse povo guerreiro e sofrido se comunica através da língua Portuguesa e Tétum, oficialmente, mas no território há mais de 14 línguas nativas. Foi colonizado por Portugal e invadido pela Indonésia em 1975. Possui um tesouro localizado em seu território marítimo, 
devido ao petróleo e gás natural que no mar timorense se encontram. Essas riquezas do Timor-Leste foram motivo de uma batalha com a Austrália. A discordância entre australianos e timorenses teve início meses antes da independência do Timor-Leste da Indonésia. A Austrália não tinha interesse em negociar, conforme o previsto pelo Direito Internacional do Mar, para evitar a perda das receitas oriundas do mar timorense. Mas, em 2018, foi realizado um Tratado Definitivo sobre as fronteiras do Timor-Leste com os australianos. Esse foi o momento histórico em que a nação obteve o reconhecimento do direito de usufruir de seu mar territorial.

A situação econômica delicada do país foi reconhecida no Tratado de Fronteiras definitivas do Timor-Leste. A escassez de recursos econômicos está relacionada à exploração dessa nação de forma arrasadora. Portugal pouco investiu durante o período de mais 400 anos em que este país foi sua colônia. Após ser libertado da dominação portuguesa, aconteceu um novo ataque ao Timor-Leste. Por mais de vinte e quatro anos, os timorenses sofreram com a ocupação da Indonésia, mas pequenos investimentos foram realizados. No entanto, a partir do período em que o povo timorense demonstrou interesse em lutar por sua independência, tudo foi destruído pelo povo indonésio. Na fase inicial da desocupação do Timor-Leste pela Indonésia, a comunidade internacional contribuiu com auxílio para reconstrução básica do país.

A independência dos timorenses não Ihes proporcionou o direito imediato de tomar posse das riquezas marítimas que thes pertenciam, devido ao fato de elas se encontrarem em seu território. Acordos provisórios sobre fronteiras, pactos que prejudicavam os timorenses foram realizados com Austrália antes de 2018. Desde 2002, o Timor-Leste reivindica a posse de seu território marítimo, conforme previsto nas normas de direito internacional, CNUD/1982. Acontece que, alguns meses antes de o Timor-Leste conquistar sua independência, a Austrália se retirou de diversos pactos internacionais.

Uma vez que os territórios marítimos do Timor-Leste e da Austrália se separam por uma distância inferior a 400 milhas náuticas, pequena distância entre os territórios das duas nações, a linha de delimitação de fronteira adotada foi definida pelo padrão da equidistância e linha mediana. Esse é o modelo previsto na Convenção das Nações 
Unidas sobre direitos do mar, de 1982, utilizada para resolução de conflitos que versem sobre territórios que se distanciam por menos de 400 milhas náuticas.

Os australianos evitaram realizar um acordo com os timorenses sobre fronteiras definitivas, conforme as normas da Convenção das Nações Unidas sobre Direitos do Mar por muitos anos. A finalidade dessa postura era desrespeitar o modo de delimitação de fronteiras marítimas, que prevê como padrão a adoção da linha mediana e equidistância em conflitos específicos sobre definição de fronteiras. O motivo do afastamento da Austrália da comunidade internacional está relacionado ao prolongamento da obtenção de lucros oriundos da exploração do mar que pertence ao povo timorense.

Após diversas tentativas de pactuar definitivamente sobre as fronteiras timorenses com Austrália, o país obteve êxito. De maneira clara e específica, em um documento que possui mais de 11 artigos, foram tratadas as fronteiras marítimas bilaterais permanentes ao longo de uma linha essencialmente equidistante entre as duas nações. O Timor-Leste teve suas fronteiras delimitadas conforme o previsto na Convenção das Nações Unidas sobre Direito do mar. Foi acordado no tratado que existe um elo indivisível entre a fronteira marítima do Timor-Leste e a Austrália. Houve o reconhecimento da existência de uma área marítima que pertence às duas nações envolvidas no pacto.

Durante a elaboração do documento, as partes partilharam as receitas da exploração dos campos do Greater Sunrise e positivaram no texto do pacto internacional a necessidade de elaborar regras que tratem da exploração dos campos da região que pertencem aos dois países. Foi estabelecido que as normas acordadas no tratado ou em seus anexos não podem ser inobservadas parcialmente por qualquer uma das partes envolvidas. Também foi regulamentado que os planos de desenvolvimento de exploração de riqueza do mar necessitam ser criados, antes do início dos procedimentos, assim como também foi acordado que as empresas petrolíferas necessitariam adquirir produtos e serviços preferencialmente do povo timorense. 
O pacto definitivo sobre fronteiras do Timor-Leste não é somente um acordo comum entre os governos de duas nações. Esse pacto dos timorenses e australianos também abrange obrigações para iniciativa privada. Foram atribuídos deveres para as empresas que realizarão a exploração do petróleo e gás da região dos campos Greater Sunrise. Elas devem contribuir para o desenvolvimento do Timor-Leste.

Muitos obstáculos precisaram ser removidos para que o Timor-Leste possa se desenvolver amplamente, apesar de ter conquistado o direito de explorar seu território marítimo. O petróleo e o gás são recursos não renováveis, ou seja, são fontes de rendas com previsão de término. Mas são fontes de renda imediatas e lucrativas. $\mathrm{O}$ desenvolvimento da educação, infraestrutura, agricultura, turismo e prestação de serviços é essencial para que se construa uma base sólida e renovável de renda a médio e longo prazo. O país enfrenta diversos obstáculos como a pouca infraestrura e baixo nível de escolaridade, porém vem crescendo muito desde 2002.

Em um mundo capitalista, é inegável que os recursos financeiros são fatores determinantes para evolução ampla de uma nação. $O$ aumento das receitas oriundas da exploração do petróleo e gás aumentará as receitas financeiras, fato que contribuirá para evolução na educação e investimentos na infraestrutura de portos e aeroportos do Timor-Leste. Se, antes do Tratado sobre fronteiras definitivas, a educação, a infraestrutura, a agricultura e a pesca industrial eram obstáculos para o desenvolvimento dos timorenses, espera-se que, após o pacto definitivo com Austrália, essa realidade se modifique.

\section{REFERÊNCIAS}

BRASIL. Decreto no 99.165, de 12 de março de 1990. Convenção das Nações Unidas sobre o Direito do Mar. Brasília: Planalto, 1990. Disponível em: https://www2.camara.leg.br/legin/fed/decret/1990/decreto-99165-12-marco-1990328535-publicacaooriginal-1-pe.html. Acesso em 15 abr.19.

DEL'OMO, Florisbal de Souza. Curso de direito internacional público. Rio de Janeiro: Forense, 2006. 
GIBERTONI, Carla Adriana Comitre. Teoria e prática do direito marítimo. Rio de Janeiro: Renovar, 1998.

GOMES, Danaciano. Timor Leste: A economia do mar: um contributo para desenvolvimento sustentável. Aveiro: Mare Liberum, 2016.

GUSMÃO, Kay Raia Xanana. Breve história do mar do Timor. In: GOVERNO DO ESTADO DO TIMOR LESTE. Novas Fronteiras: conciliação histórica das fronteiras marítimas no mar do timor. Dili: Gabinete das Fronteiras marítimas, 2018.

MARCONI, Maria de Andrade, Lakatos, Eva, Maria. Fundamentos da metodologia cientifica. São Paulo: Atlas. 2003.

MARITIME BOUNDARY OFFICE. New frontiers: Timor-Leste's historic conciliation on maritime boundaries in the timor sea. [S. I.], 2015. Disponível em: http://www.gfm.t//wp-content/uploads/2015/11/Website-map-of-Timor-Sea.pdf. Acesso em: 04 maio 2019.

MATTOS, Adherbal. Meira. O novo direito do mar. Rio de Janeiro: Renovar. 1996.

PEREIRA, Eliana Sofia da Silva. Contributo crítico para a compreensão do regime do Mar de Timor à luz do Direito Internacional. 2013. 87 f. Dissertação. (Mestrado em Ciências Jurídicas Internacionais) Faculdade de direito- Universidade Nova de Lisboa, 2013. p.14. Disponível em: https://run.unl.pt/bitstream/10362/17481/1/Pereira_2013.pdf. Acesso em: 01 abr. 2019.

REPÚBLICA DEMOCRÁTICA DE TIMOR-LESTE. Ministério das finanças. Orçamento geral do Estado 2018. Díli: Gabinete Ministerial, 2018. p. 7. Disponível em: https://www.mof.gov.t//wp-content/uploads/2018/08/BB5_Port.pdf. Acesso em: 15 maio 2019. 
REPUBLICA DEMOCRÁTICA DO TIMOR LESTE. História do Timor Leste. Governo do Timor Leste, Dili, [s. d.]. Disponível em: http://timor-leste.gov.tl/?p=29\&lang=pt. acesso em: 05 maio 2019.

REZEK, José Francisco. Direito internacional público: curso elementar. 10. ed. rev. e atual. São Paulo: Saraiva, 2005.

RIBEIRO, Marilda, Rosado de Sá. Direito do petróleo. 3. ed. rev. atual. e ampl. Rio de Janeiro: Renovar, 2018.

TIMOR LESTE; AUSTRÁLIA. Tratado sobre fronteiras marítimas entre Timor Leste e Austrália que estabelece as respectivas fronteiras do mar do Timor Leste. Nova York: [s.n.], 2018. p. 1. Disponível em: http://www.gfm.t//wpcontent/uploads/2018/03/Port-Timos-Sea-Maritime-BoundaryTreaty_Portuguese.pdf. Acesso em:04 maio 2018.

TIMOR SEA JUSTICE. All of the contested oil \& gas fields are on EastTimor's side of the median line ie closer to \#Timor than Australia. Dili, 01 mar. 2016. Tiwitte: @timor sea justice. Disponível em: https://twitter.com/TimorSeaJustice/status/704895304701763584. Acesso em: 25 maio. 2019.

ZANELLA, T. V. Curso de direito do mar. Curitiba: Juruá, 2013.

\section{APÊNDICE - REFERENCIAS DE NOTA DE RODAPÉ}

3. GOMES, Danaciano. Timor-Leste: A economia do mar: um contributo para desenvolvimento sustentável. Aveiro: Mare Liberum, 2016.

4. GUSMÃO, Kay Raia Xanana. Breve história do mar do Timor. In: GOVERNO DO ESTADO DO TIMOR LESTE. Novas Fronteiras: conciliação histórica das fronteiras marítimas no mar do timor. Dili: Gabinete das Fronteiras marítimas, 2018. p. 6. 
5. RIBEIRO, Marilda, Rosado de Sá. Direito do Petróleo. 3. ed. rev. atual. e ampl. Rio de Janeiro: Renovar, 2018.

6. RIBEIRO, Marilda, Rosado de Sá. Direito do Petróleo. 3. ed. rev. atual e ampl. Rio de Janeiro Renovar, 2018.

7. GOMES, Danaciano. Timor Leste: a economia do mar: um contributo para desenvolvimento sustentável. Aveiro: Mare Liberum, 2016.

8. MARCONI, Maria de Andrade, Lakatos, Eva, Maria. Fundamentos da metodologia cientifica. São Paulo: Atlas. 2003.

9. GUSMÃO, Kay Raia Xanana. Breve história do mar do Timor. In: GOVERNO DO ESTADO DO TIMOR LESTE. Novas Fronteiras: conciliação histórica das fronteiras marítimas no mar do timor. Dili: Gabinete das Fronteiras marítimas, 2018. p. 7-8.

10. MARITIME BOUNDARY OFFICE. New frontiers: Timor-Leste's historic conciliation on maritime boundaries in the timor sea. [S. I.], 2015. Disponível em: http://www.gfm.tl/wp-content/uploads/2015/11/Website-map-of-Timor-Sea.pdf. Acesso em: 04 maio 2019.

11. GOMES, Danaciano. Timor Leste: A economia do mar: um contributo para desenvolvimento sustentável. Aveiro: Mare Liberum, 2016. p. 35-36.

12. GOMES, Danaciano. Timor Leste: A economia do mar: um contributo para desenvolvimento sustentável. Aveiro: Mare Liberum, 2016. p. 37 e 38

13. PEREIRA, Eliana Sofia da Silva. Contributo crítico para a compreensão do regime do Mar de Timor à luz do Direito Internacional. 2013. 87 f. Dissertação. (Mestrado em Ciências Jurídicas Internacionais) Faculdade de direito- Universidade Nova de Lisboa, 2013. p.14. Disponível em: https://run.unl.pt/bitstream/10362/17481/1/Pereira_2013.pdf. Acesso em: $01 \mathrm{abr}$. 2019. 
14. PEREIRA, Eliana Sofia da Silva. Contributo crítico para a compreensão do regime do Mar de Timor à luz do Direito Internacional. 2013. 87 f. Dissertação. (Mestrado em Ciências Jurídicas Internacionais) Faculdade de direito- Universidade Nova de Lisboa, 2013. p.14. Disponível em: https://run.unl.pt/bitstream/10362/17481/1/Pereira_2013.pdf. Acesso em: 01 abr. 2019.

15. TIMOR LESTE; AUSTRÁLIA. Tratado sobre Fronteiras Marítimas entre Timor Leste e Austrália que estabelece as respectivas fronteiras do mar do Timor Leste. Nova York: [s.n.], 2018. p. 1. Disponível em: http://www.gfm.t//wpcontent/uploads/2018/03/Port-Timos-Sea-Maritime-Boundary-

Treaty_Portuguese.pdf. Acesso em:04 maio 2018.

16. PEREIRA, Eliana Sofia da Silva. Contributo crítico para a compreensão do regime do Mar de Timor à luz do Direito Internacional. 2013. 87 f. Dissertação. (Mestrado em Ciências Jurídicas Internacionais) Faculdade de direito- Universidade Nova de Lisboa, 2013. p.14. Disponível em: https://run.unl.pt/bitstream/10362/17481/1/Pereira_2013.pdf. Acesso em: 01 abr. 2019.

17. MATTOS, Adherbal. Meira. O novo Direito do Mar. Rio de Janeiro: Renovar. 1996. p. 04

18. RIBEIRO, Marilda, Rosado de Sá. Direito do Petróleo. 3. ed. rev. atual. e ampl. Rio de Janeiro: Renovar, 2018.

19. Zona Contígua é Faixa entre o mar territorial e o alto-mar, fixada entre 12 e 24 milhas, na qual o Estado exerce sua jurisdição sobre atividades marítimas e sobre diversos interesses nacionais.

20. Plataforma continental é definida como uma faixa de terra submersa, em toda a extensão do litoral do continente. Geralmente, a plataforma possui uma extensão de 70 a $90 \mathrm{~km}$, e profundidade de 200 metros, até atingir as bacias oceânicas. 
21. Nota explicativa: Águas adjacentes são aquelas que banham as margens do território de uma nação.

22. ZANELLA, T. V. Curso de Direito do Mar. Curitiba: Juruá, 2013.

23. ZANELLA, T. V. Curso de Direito do Mar. Curitiba: Juruá, 2013.

24. RIBEIRO, Marilda, Rosado de Sá. Direito do Petróleo. 3. ed. rev. atual. e ampl. Rio de Janeiro: Renovar, 2018.

25. REZEK, José Francisco. Direito Internacional Público: curso elementar. 10. ed. rev. e atual. São Paulo: Saraiva, 2005. p.307

26. BRASIL. Decreto no 99.165, de 12 de março de 1990. Convenção das Nações Unidas sobre o Direito do Mar. Brasília: Planalto, 1990. Disponível em: https://www2.camara.leg.br/legin/fed/decret/1990/decreto-99165-12-marco-1990328535-publicacaooriginal-1-pe.html. Acesso em 15 abr.19.

27. GIBERTONI, Carla Adriana Comitre. Teoria e prática do direito marítimo. Rio de Janeiro: Renovar, 1998. p.33.

28. GOMES, Danaciano. Timor Leste: A economia do mar: um contributo para desenvolvimento sustentável. Aveiro: Mare Liberum, 2016. p.51

29. PEREIRA, Eliana Sofia da Silva. Contributo crítico para a compreensão do regime do Mar de Timor à luz do Direito Internacional. 2013. 87 f. Dissertação. (Mestrado em Ciências Jurídicas Internacionais) Faculdade de direito- Universidade Nova de Lisboa, 2013. p.56. Disponível em: https://run.unl.pt/bitstream/10362/17481/1/Pereira_2013.pdf. Acesso em: $01 \mathrm{abr}$. 2019.

30. GOMES, Danaciano. Timor Leste: A economia do mar: um contributo para desenvolvimento sustentável. Aveiro: Mare Liberum, 2016. p.110 e 111 
31. RIBEIRO, Marilda, Rosado de Sá. Direito do Petróleo. 3. ed. rev. atual. e ampl. Rio de Janeiro: Renovar, 2018. P. 74 à 80

32. GUSMÃO, Kay Raia Xanana. Breve história do mar do Timor. In: GOVERNO DO ESTADO DO TIMOR LESTE. Novas Fronteiras: conciliação histórica das fronteiras marítimas no mar do timor. Dili: Gabinete das Fronteiras marítimas, 2018.

33. DEL'OMO, Florisbal de Souza. Curso de Direito Internacional Público. Rio de Janeiro: Forense, 2006. p. 292.

34. TIMOR SEA JUSTICE. All of the contested oil \& gas fields are on EastTimor's side of the median line ie closer to \#Timor than Australia. Dili, 01 mar. 2016. Tiwitte: @timor sea justice. Disponível em: https://twitter.com/TimorSeaJustice/status/704895304701763584. Acesso em: 25 maio. 2019.

35. GUSMÃO, Kay Raia Xanana. Breve história do mar do Timor. In: GOVERNO DO ESTADO DO TIMOR LESTE. Novas Fronteiras: conciliação histórica das fronteiras marítimas no mar do timor. Dili: Gabinete das Fronteiras marítimas, 2018. p. 34 e 35

36. DEL'OMO, Florisbal de Souza. Curso de Direito Internacional Público. Rio de Janeiro: Forense, 2006. p. 292

37. DEL'OMO, Florisbal de Souza. Curso de Direito Internacional Público. Rio de Janeiro: Forense, 2006. p. 292

38. REPUBLICA DEMOCRÁTICA DO TIMOR LESTE. História do Timor Leste.

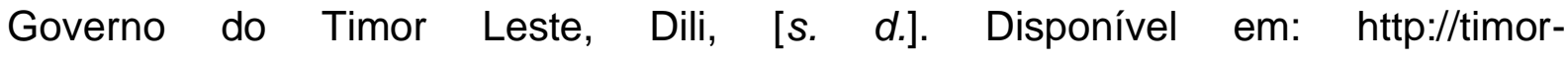
leste.gov.tl/?p=29\&lang=pt. acesso em: 05 maio 2019.

39. TIMOR LESTE; AUSTRÁLIA. Tratado sobre Fronteiras Marítimas entre Timor Leste e Austrália que estabelece as respectivas fronteiras do mar do Timor Leste. Nova York: [s.n.], 2018. p. 1. Disponível em: http://www.gfm.tl/wp- 
content/uploads/2018/03/Port-Timos-Sea-Maritime-Boundary-

Treaty_Portuguese.pdf. Acesso em:05 maio 2018.

40. PEREIRA, Eliana Sofia da Silva. Contributo crítico para a compreensão do regime do Mar de Timor à luz do Direito Internacional. 2013. 87 f. Dissertação. (Mestrado em Ciências Jurídicas Internacionais) Faculdade de direito- Universidade Nova de Lisboa, 2013. p.14-15. Disponível em: https://run.unl.pt/bitstream/10362/17481/1/Pereira_2013.pdf. Acesso em: 01 abr. 2019

41. TIMOR LESTE; AUSTRÁLIA. Tratado sobre Fronteiras Marítimas entre Timor Leste e Austrália que estabelece as respectivas fronteiras do mar do Timor Leste. Nova York: [s.n.], 2018. p. 1. Disponível em: http://www.gfm.tl/wpcontent/uploads/2018/03/Port-Timos-Sea-Maritime-Boundary-

Treaty_Portuguese.pdf. Acesso em:05 maio 2018.

42. TIMOR LESTE; AUSTRÁLIA. Tratado sobre Fronteiras Marítimas entre Timor Leste e Austrália que estabelece as respectivas fronteiras do mar do Timor Leste. Nova York: [s.n.], 2018. p. 1. Disponível em: http://www.gfm.t//wpcontent/uploads/2018/03/Port-Timos-Sea-Maritime-Boundary-

Treaty_Portuguese.pdf. Acesso em:05 maio 2018.

43. GIBERTONI, Carla Adriana Comitre. Teoria e prática do direito marítimo. Rio de Janeiro: Renovar, 1998. p. 33.

44. TIMOR LESTE; AUSTRÁLIA. Tratado sobre Fronteiras Marítimas entre Timor Leste e Austrália que estabelece as respectivas fronteiras do mar do Timor Leste. Nova York: [s.n.], 2018. p. 1. Disponível em: http://www.gfm.tl/wpcontent/uploads/2018/03/Port-Timos-Sea-Maritime-Boundary-

Treaty_Portuguese.pdf. Acesso em:05 maio 2018.

45. TIMOR LESTE; AUSTRÁLIA. Tratado sobre Fronteiras Marítimas entre Timor Leste e Austrália que estabelece as respectivas fronteiras do mar do Timor Leste. Nova York: [s.n.], 2018. p. 1. Disponível em: http://www.gfm.tl/wp- 
content/uploads/2018/03/Port-Timos-Sea-Maritime-Boundary-

Treaty_Portuguese.pdf. Acesso em:05 maio 2018.

46. TIMOR LESTE; AUSTRÁLIA. Tratado sobre Fronteiras Marítimas entre Timor Leste e Austrália que estabelece as respectivas fronteiras do mar do Timor Leste. Nova York: [s.n.], 2018. p. 1. Disponível em: http://www.gfm.tl/wpcontent/uploads/2018/03/Port-Timos-Sea-Maritime-BoundaryTreaty_Portuguese.pdf. Acesso em:05 maio 2018.

47. TIMOR LESTE; AUSTRÁLIA. Tratado sobre Fronteiras Marítimas entre Timor Leste e Austrália que estabelece as respectivas fronteiras do mar do Timor Leste. Nova York: [s.n.], 2018. p. 1. Disponível em: http://www.gfm.tl/wpcontent/uploads/2018/03/Port-Timos-Sea-Maritime-Boundary-

Treaty_Portuguese.pdf. Acesso em:05 maio 2018.

48. GOMES, Danaciano. Timor Leste: A economia do mar: um contributo para desenvolvimento sustentável. Aveiro: Mare Liberum, 2016. p. 59.

49. REPUBLICA DEMOCRÁtICA DO TIMOR LESTE. História do Timor Leste.

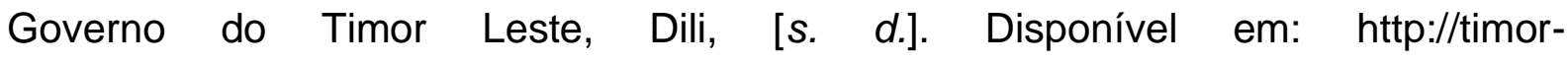
leste.gov.tl/?p=29\&lang=pt. Acesso em: 05 maio 2019.

50. O PRIMEIRO dia no Timor Leste. In: PARCEIROS pela paz. Dili, 06 jul. 2011. Disponível em: https://parceirospelapaz.wordpress.com/category/timor-leste/. Acesso em: 25 maio 2019.

51. REPÚBLICA DEMOCRÁtICA DE TIMOR-LESTE. Ministério das finanças. Orçamento geral do Estado 2018. Díli: Gabinete Ministerial, 2018. p. 7. Disponível em: https://www.mof.gov.tl/wp-content/uploads/2018/08/BB5_Port.pdf. Acesso em: 15 maio 2019.

52. TIMOR LESTE; AUSTRÁLIA. Tratado sobre Fronteiras Marítimas entre Timor Leste e Austrália que estabelece as respectivas fronteiras do mar do Timor Leste. Nova York: [s.n.], 2018. p. 1. Disponível em: http://www.gfm.tl/wp- 
content/uploads/2018/03/Port-Timos-Sea-Maritime-Boundary-

Treaty_Portuguese.pdf. Acesso em: 19 maio 2018.

53. GOMES, Danaciano. Timor Leste: A economia do mar: um contributo para desenvolvimento sustentável. Aveiro: Mare Liberum, 2016.

54. REPUBLICA DEMOCRÁTICA DO TIMOR LESTE. História do Timor Leste. Governo do Timor Leste, Dili, $\left[\begin{array}{ll}s . & d .\end{array}\right]$. Disponível em: http://timorleste.gov.t//p=29\&lang=pt. acesso em: 05 maio 2019

55. TIMOR LESTE; AUSTRÁLIA. Tratado sobre Fronteiras Marítimas entre Timor Leste e Austrália que estabelece as respectivas fronteiras do mar do Timor Leste. Nova York: [s.n.], 2018. p. 1. Disponível em: http://www.gfm.tl/wpcontent/uploads/2018/03/Port-Timos-Sea-Maritime-Boundary-

Treaty_Portuguese.pdf. Acesso em: 19 maio 2018.Acessado: 05/05/19

56. TIMOR LESTE; AUSTRÁLIA. Tratado sobre Fronteiras Marítimas entre Timor Leste e Austrália que estabelece as respectivas fronteiras do mar do Timor Leste. Nova York: [s.n.], 2018. p. 1. Disponível em: http://www.gfm.tl/wpcontent/uploads/2018/03/Port-Timos-Sea-Maritime-Boundary-

Treaty_Portuguese.pdf. Acesso em:05 maio 2018.

57. TIMOR LESTE; AUSTRÁLIA. Tratado sobre Fronteiras Marítimas entre Timor Leste e Austrália que estabelece as respectivas fronteiras do mar do Timor Leste. Nova York: [s.n.], 2018. p. 1. Disponível em: http://www.gfm.tl/wpcontent/uploads/2018/03/Port-Timos-Sea-Maritime-Boundary-

Treaty_Portuguese.pdf. Acesso em:05 maio 2018.

58. GOMES, Danaciano. Timor Leste: A economia do mar: um contributo para desenvolvimento sustentável. Aveiro: Mare Liberum, 2016

59. GOMES, Danaciano. Timor Leste: A economia do mar: um contributo para desenvolvimento sustentável. Aveiro: Mare Liberum, 2016. p.114-115. 
60. GOMES, Danaciano. Timor Leste: A economia do mar: um contributo para desenvolvimento sustentável. Aveiro: Mare Liberum, 2016.

61. REPÚBLICA DEMOCRÁTICA DE TIMOR-LESTE. Ministério das finanças. Orçamento geral do Estado 2018. Díli: Gabinete Ministerial, 2018. Disponível em: https://www.mof.gov.tl/wp-content/uploads/2018/08/BB5_Port.pdf. Acesso em: 15 maio 2019.

62. GOMES, Danaciano. Timor Leste: A economia do mar: um contributo para desenvolvimento sustentável. Aveiro: Mare Liberum, 2016.

Enviado: Agosto, 2019.

Aprovado: Dezembro, 2019. 